\title{
Common Knowledge: Bodies, Evidence and Expertise in Early Modern Germany
}

\section{J. Andrew Mendelsohn and Annemarie Kinzelbach}

\section{Introduction}

How we know: if there were one answer to this question, historians and social scientists, even most philosophers, would not be asking it. When we study knowledge, we usually see different knowing practices: scholarly, artisanal, philosophical, experimental, mathematical. This expectation holds across the arts and sciences and beyond, even in the early modern period. The knowing practices of artisans, physicians and medical practitioners of all sorts, jurists, farmers, theologians, merchants, engineers, actuaries, householding women, administrators or indeed "the state" are all now under study for their relevance - and hence necessarily their distinctive relevance - to the history of science broadly conceived. ${ }^{1}$ The fading of the idea of "the" scientific method, itself relatively recent, spurred the search for styles or "ways of knowing" or far-reaching practices of quantifying, visualizing, being objective, establishing facts, managing information and renewed the study of transfer across domains and learned/lay divides without assuming diffusion from above or from European centers. ${ }^{2}$ All this research presupposes plurality. Distinction is especially evident in public settings, where special knowledge typically is claimed by groups or individuals and put to use by states, courts of law, and communities, and where historians study the construction and contestation of expertise as well as the interaction of different "experts" - scientific, medical, legal, or more specialized - with each other and with "lay" people. ${ }^{3}$

Yet the early modern period, we propose, offers an opposite story about the same plurality of knowers and domains, a story that also promises insight into modern times. It is a history of common rather than uncommon knowing, of shared empirical rational practices rather than specialties and interactions, a history that the very focus on "expertise" tends to obscure. We tell one version of this history through a collection of stories. They were cases in their time, and in this paper they stand for other similar ones. They take place where we would expect them least: in those places of distinction among knowers, public settings.

Hans Mohr, Highest Justice of the Free Imperial City of Frankfurt am Main, wanted to know "whether the cranium and the dura and pia mater had been damaged by the beating."

This seems a question for the surgeon. But it was asked of Katharina Hansenn, housewife. And she answered. ${ }^{4}$ 
It was Thursday, the twenty-first of May 1551. Mohr's task was to provide evidence (beweisen) as to whether Anna, wife of Martin Rode, had died from maltreatment by her husband or from unrelated illness. ${ }^{5}$ So in the Rathaus that day and the following week, he questioned 21 "witnesses." They ranged from university-educated doctors to barber-surgeons to neighbors and relatives. There is nothing remarkable in this. Until we notice that Justice Mohr was asking doctors and housewives the same questions. ${ }^{6}$ All were expected to answer questions we would call "medical" or "for experts," and by and large they did. Moreover, as we shall see, these questions concerned both what was seen (as one would ask of an eyewitness) and how and why death occurred (as one would ask of an expert witness). This is the observation from which the argument of this paper unfolds. The central claim is that groups of widely differing status, education, occupation, and experience in fact shared empirical rational practices. These were practices of observation, description, explanation, and argument.

This argument unfolds across a range of at least five different kinds of case of inquiry for public decision: from the diseased former soldier accused of endangering his community (purity and danger, public health) to the artisan family seeking annulment of a marriage (family economy, material production and human reproduction) to surgeons under investigation for malpractice (guild regulation of a trade and practical art) to individuals claiming community resources (charitable care, poor relief) to classical forensic cases like that in which Hausfrau Hansenn testified over the body of Anna (conflict and violence). These situations of uncertainty or disagreement occurred in a variety of polities in the Holy Roman Empire between the 1510s and the 1650s. Resolving them in ways acceptable to their communities involved making observations and arguments about the body in health and illness, anatomy, diet, materia medica, relations between bodies and their natural and human environments, law, and the practical arts. The cases come from three kinds of source, each representing an agency of inquiry and evaluation: the archives of a government (Frankfurt am Main, a city-state), a medical faculty (Tübingen, university of a territorial state, the Duchy of Württemberg), and a guild (or more precisely the sworn jurymen master barber-surgeons nominated from their guild in a major center of wealth and the arts, Ulm). ${ }^{7}$ Studies of public cases involving human bodies usually concern one or two of the classic forensic types (infanticide, insanity) and one or two kinds of participant, such as physicians. Or they focus on the female body. ${ }^{8}$ The present study makes a simple move: to study the full range of participants and a variety of situations at once, involving both male and female bodies. This method is, moreover, to read without assuming who knows and to look for commonality of practice as much as construction of difference. Each case 
examined here, we find, displays the same broad participation and commonality across difference that is evident in the story of the inquiry into Anna's death in Frankfurt in 1551.

This commonality is unexpected: generally for the reasons already given and specifically because we know to expect conflict and strategies of distinction among health practitioners in all their early modern variety - doctors, midwives, barber-surgeons, herb women, apothecaries, "empirics" and purveyors of "secret remedies," clerics, bonesetters, astrologers, and so on - and from others claiming knowledge in public settings. ${ }^{9}$ Moreover, the shared language (humoral, Galenic) by which the body - especially the female body - was understood by doctors and patients and in both learned and vernacular medical literature is well known, ${ }^{10}$ but is not the same as shared practices of inspecting, describing, and constructing or countering evidence and explanation. In the ever wider and more various social history of knowledge, as Peter Burke writes in his survey under that name, medicine exemplifies the "plurality of knowledges."11 This is a reason to consider broadly the implications of the cases presented in this paper.

There are further reasons we can expect to learn generally about knowledge, society, and expertise by studying cases involving the human body. The first is range. Trials, inquiries, inspections: cases we consider range from criminal justice to civil contracts, from public health to municipal aid to guild regulation of trades, and generally across "Policey," the broad early modern term for the tens of thousands of ordinances and countless individual proceedings that comprised social, economic, and environmental regulation. ${ }^{12}$ Thus our findings are not particular to this or that kind of legal or administrative process. ${ }^{13}$ There were formal differences between domains such as law (Recht), police, guild, and market and between proceedings such as inspection $(\mathrm{Schau})$ and trial in court (Gericht). Yet focusing on bodies and their environments brings together cases from all these domains and brings their similarities into view. ${ }^{14}$ This omnipresence of the body entails a second reason we stand to learn from cases involving it. Healers testified throughout the medieval and early modern periods, while representatives of other occupations that could claim special knowledge and experience and that came to be called expert rarely did so until the 18th and 19th centuries. ${ }^{15}$ Healers had, on the other hand, no monopoly: knowledge of the body and of natural environments and substances in relation to health was widespread, in both oral and written form and in the form of domestic practice. ${ }^{16}$ This conjunction of contraries - being the knowers most called upon by the polity and, at the same time, sharing knowledge with many others - will test, in case studies, expertise as the currently standard way of thinking about practical knowledge in action.

Why, then, early modern Germany? Recent research on politics in the Holy Roman Empire between the 16th and the 18th centuries has revealed a staggering degree of participation 
and initiative "from below" in the political life of communities, especially cities, and thus essentially in their government. ${ }^{17}$ This has been shown for free imperial cities yet also where less expected: in territorial "police" states and in so-called inquisitorial criminal justice systems, which had long been the very image of expert-based government and social control - and in Anglo-American historiography of science and medicine still are. ${ }^{18}$ Broad political participation on one hand and, on the other, prevalence of university-trained knowers in government in the part of Europe that gave us cameralism and "sciences of state" (Staatswissenschaften): this conjunction of apparent contraries makes early modern German public cases good for thinking about these matters at large. Moreover, the new history of political participation and interaction does not look at participants as knowers. And it virtually ignores the practices of artisanal groups and learned ones, which are the subject of separate old literatures on guilds and universities and on law, medicine, theology, and humanism, and of separate newer literatures on artisanal knowledge and how-to, learned practices, political counsel, jurists practicing rather than prescribing, academic ritual, and "scholars in action" - altogether difficult to grasp except as different kinds and cultures of expertise. ${ }^{19}$ Public cases allow us to look instead at everyone in the same settings, reporting on and judging the same situations.

So inclusive is this story of knowing that it includes one other character not usually in the cast: the accused. ${ }^{20}$ Studied by historians mainly as the human objects of inquiry, ${ }^{21}$ they were equally its subjects - sometimes more than equally, when they won their cases. This is the focus of the first section of the paper. The second section broadens to show that all kinds of participants dealt with the same questions using the same or comparable sorts of empirical rational practice. This did not make participants interchangeable. Groups differed in education, occupation, and experience and in function in public proceedings. At times they competed for authority. Instead of starting from groups and examining their interaction, ${ }^{22}$ however, we start from what all kinds of participant did throughout a trial, inspection, or inquiry and ask, in section three, what happened to difference and commonality along the way.

\section{Subjects of Knowledge}

Creating information, controlling knowledge: these capacities, our case studies suggest, were not restricted to city councillors, jurymen, judges, their advisors, and medical "experts." They were also in the hands of the accused, which were less bound than usually imagined, and in the hands of wider informed publics. Contrary to principles of inquisition and contrary to the long tradition of regarding criminal law as an arm of the state for social control, we know from historical research since the 1990s that most policing action and most judicial proceedings in 
early modern Europe were initiated by individuals rather than by the authorities. ${ }^{23}$ Moreover, the majority of trials for capital crimes, even in the age of the so-called Carolina (from Constitutio Criminalis Carolina) and its precursor codifications of inquisitorial criminal justice in the Holy Roman Empire, roughly 1500-1800, ended with much milder punishments or with various forms of peaceful conflict-resolution between the parties of victim and accused. All such outcomes were determined by very broad written and oral participation by relatives, friends, communities, and the accused him or herself. Unexamined in this new history of criminal justice as "consensual practice" and "clearing place" for conflicts are questions of evidence and argument, knowledge and expertise. ${ }^{24}$ What we show in this section is, first, the knowledge component of such activity and, second, that patterns of informed action reached far beyond proceedings of criminal law to other situations that turned on evaluating the conditions of and events around a human body and in which observations were made, evidence produced and debated, and judgments delivered.

The trial of Martin Rode, with its medical arguments and many medical witnesses, seems to exemplify the rising role of medical expertise in the 16th century. ${ }^{25}$ Yet the trial and its associated inquiries were in many ways created through the knowledgeable action of the accused and of a wide public. This was not because of Rode's social status: he is addressed in documents as barrel-maker, indicating a modest income; according to witnesses, he was also innkeeper and owner of a vineyard, indicating a higher income. ${ }^{26}$ Rumors that Rode had hit his wife Anna such that she died travelled at least as far as Heidelberg, almost a hundred kilometres away. ${ }^{27}$ The governors of Frankfurt could not ignore such rumors without appearing to neglect central tasks of an imperial city's council: to protect the rights of burghers, to ensure justice and to reestablish "order" when it was disturbed. The sheer number of Rode-related entries minuted in the council proceedings of 1551 indicates that the challenge was taken up. ${ }^{28}$ The part played by doctors and barber-surgeons increased rather than resolved uncertainty: results of examination and partial autopsy of Anna's corpse tended to absolve Rode. Partly on that basis, the accused and his legal counsel asserted a right to call witnesses. Highest Justice Mohr tried to prevent this and to keep to a purely inquisitorial form of trial in which he alone would decide who testified. But the accused prevailed over the inquisitor. ${ }^{29}$ In fact, the questions put to witnesses in the file titled “Hans Mohr Highest Worldly Justice against Martin Rode Barrelmaker” were mainly generated not by Mohr in his fact-finding function, as inquisitor, but by the defense mounted by the barrelmaker and his lawyer. ${ }^{30}$ Thus although the case turned on questions we would call medical, it was being shaped far less by medical expertise than as a kind of informed debate that began with public opinion ("rumor"), continued in meetings of an elected governing council, and 
reached fullest form in hearings that, through the knowledgeable action of the accused and his lawyer, created and tested alternative accounts of an event in the physical and human world.

None of this was new in 1550. Before exploring the Rode hearings, let us consider an earlier, simpler yet analogous case. In 1517 in Frankfurt, Clauß Guntram was charged with killing a man named Genßhenn. The defendant claimed that he had wounded Genßhenn unwillingly in an act of self-defence and that his alleged victim did not die from this injury but had in fact been cured before he died and that an intervening illness had led to his death. Guntram named a number of witnesses, who testified that the stab injury had been completely healed after less than three weeks and that Genßhenn had thereafter been back to work, hauling wood, and walking distances, and even celebrating his recovery. ${ }^{31}$ Among these witnesses was a barber-surgeon. Yet the structure of such medical arguments and emphasis on evidence of recovery from injury reflected the state of the art in contemporary vernacular "lay" legal texts, such as the widely circulated Layen-Spiegel or "Layman's Guide" to civil and criminal procedure, first published at Augsburg in 1509 and in thirteen more editions in the 16th century and would later appear in the Carolina itself, which was after all not only a new codification, but a lay guide, in German not Latin, to criminal procedure. ${ }^{32}$ Such texts guided lay inquisitors, but also the accused objects of inquiry.

Trials for criminal offenses were not the only kind of proceeding in which the objects of empirical inquiry became its subjects. Beyond autopsy and examination of wounds and corpses lay a wide domain of official inspection (usually Schau, sometimes Besichtigung) of the condition of human bodies, ranging from suspected leprosy to cases for poor relief and, as we show below, to cases involving marriage and family economy. Central to the development of such procedures was leprosy inspection, which for centuries was very widely practised and took place in monasteries, in leprosaria outside of cities, in senate rooms of medical faculties or the dean's own home, and in spaces specially designated by city governments. ${ }^{33}$

Late medieval clergy, nobility, and eventually less privileged members of society countered accusations of leprosy by demanding that they be examined by medical doctors. ${ }^{34}$ Or they challenged the results of such examinations and appealed their cases. ${ }^{35}$ Official town physicians complained of people hiding leprosy, but also of poor people simulating the disease by maltreating their skin. ${ }^{36}$ For a leprosy certificate could be a ticket indoors, as could one for a new condition manifested on the surfaces of people's bodies, the so-called French pox. As opportunities for subsidised medical treatment increased in the 16th century, ailing inhabitants of towns manoeuvred for access to charitable or municipal institutions. This entailed passing a medical examination - with a positive result. ${ }^{37}$ In 1544, for example, Caspar Vögelin of the 
south German imperial city of Nördlingen reported himself to official town doctor Johann Widman. The certificate issued by Dr. Widman supported Vögelin's account of his condition and his suggestion that he be funded for treatment at a mineral spa: this had a chance of curing quickly and thus more cheaply than other methods. ${ }^{38}$ Agreement was at once medical and economic. Inspection was not "expertise" imposed on the "public" or laypeople as objects of inquiry and knowledge. Empirical and evaluative practice that made up such "expertise" was Vögelin's as well as Dr. Widman's.

Not all such cases went so smoothly. More conflicted ones show still more the variety of components that could make up knowledgeable behavior. In 1594, again in Nördlingen, Maria Adam showed her skin problems to the town barber-surgeon "in office" (im Amt). She did not get the result she expected: a certificate entitling her to months of living and being cared for in the pox-house at communal expense. So she took her case to the junior physician in office, to whom she named signs that she held were those of sickness and which according to the barbersurgeon she had not mentioned before. And when she found that this physician agreed with the barber-surgeon against her interpretations and expectations, she appealed to the senior physician in office. ${ }^{39}$ Of course we can see this as pursuing one's interests; more interestingly we can see it as a knowledge struggle, over rival diagnoses. Confident knowing of one's history and condition, capacity to present and represent oneself with assurance to experts, culturally scripted behaviors of women's obstinacy, civil defiance, and attempted fraud: each of these possible ways of interpreting events would be one or another contextual or analytical construction of Maria Adam's informed behaviour.

The most interesting such cases are those in which the person in question seems, on the face of it, to be thoroughly at the mercy of power and knowledge. In 1656 seventy-two-year-old former soldier Martin Naff appeared at the Medical Faculty of Tubingen to be examined by members of the faculty and a surgeon. ${ }^{40}$ He had been sent by his regional bailiff, whose office was in the town of Horb on the Neckar (about 30 kilometers from Tubingen) and who was the local representative of the policing powers of the Habsburg Empire. ${ }^{41}$ Naff's medical history as related in a letter from the bailiff to the faculty revealed years of skin disease - and years of accusations, banishments, and in the end even incarceration. Neighbors had once "accused" Naff of being afflicted with Malazej (leprosy). This accusation was upheld and resulted in his separation from family, income, and community. In 1653 he returned with a testimony from the Collegium Medicum in far-away Strasbourg stating that he was free of leprosy. The following year, around Christmas 1654, he used an ointment, and a rash broke out on his head four weeks later. Instead of treating him, the barber-surgeon whom he consulted denounced Naff to the 
authorities as having the so-called French disease. Naff spent the next four weeks in prison. The bailiff"s letter to the Tubingen faculty listed the allegedly "infected" parts of Naff's body and demanded certainty (gewissheit) concerning the nature of the disease. Told in this way, the tale of Martin Naff is one of a man pushed around and battered by knowledgeable governing forces around him.

Looked at more closely, however, we find the opposite. Naff's behavior exemplifies what historians of the patient have revealed to be common patterns of self-directed selection of remedies and choosing of practitioners. ${ }^{42}$ Naff himself procured and used the guethleuth salben, an ointment either specifically used by lepers or produced by the inmates of a leprosarium, even as he denied being leprous. ${ }^{43}$ Naff himself procured from a barber-surgeon a bandage to avoid contamination. All in all he consulted four barber-surgeons, among these a travelling Swiss and a “foreigner". Moreover, he evaluated medical treatments by refusing to pay selected bills. Not paying was not simply pecuniary or deviant behavior, but a version of the negotiated patientpractitioner relationship that was governed in other places, as Gianna Pomata has shown for Bologna, by written contracts for cure and tribunals for disagreements. ${ }^{44}$ And, finally, it was Martin Naff himself who took the initiative of seeking inspection and certification by another authority, the Strasbourg Collegium, and who undertook the long journey for this.

And there is more, lest this seem mainly a history of power without much knowledge and information in it. Let us rejoin Naff under inspection by the Tubingen medical faculty. Contrary to accusations of infection, Naff argued that the condition of his health and skin derived from hardship during his earlier life as a soldier, from the bad dietary habits he acquired through lack of female company, and from the noxious vapors emanating from the walls of the various prisons to which he had been confined, which had damaged his rohr (bone or penis). The faculty decided the same. It responded to the bailiff that Naff's "scabies and varices" were not contagious but resulted from his old age and from alterations in his blood due to dietetic mistakes, frost, and the appalling conditions under which he had been living, and that the resulting signs had been misinterpreted as those of leprosy or the French disease. ${ }^{45}$ Inspection from above and patient narrative from below were one. The professors were not merely informed by the man who was the object of inquiry: the faculty's evaluation (Gutachten) was virtually Naff's own account. Moreover, the faculty's report was written under and signed by its dean, Samuel Hafenreffer, author of the first major book on skin diseases in Germany, which went through seven editions in the mid 17 th century. ${ }^{46}$ The professor and leading authority shared interpretive and explanatory practice with the old soldier. 


\section{Public of Experts}

Ways of evaluating the condition of human bodies between health, disease, and danger were shared not only by inspectors and inspected, but also by wider publics. Fellow inhabitants of Naff's hamlet, Eutingen, participated in knowing and decision-making in situations of uncertainty.

For some time clamor rings out and rumor is spread that he [Naff] is tainted with the epidemic French Disease. This induces abhorrence in many inhabitants of the hamlet, and everyone is saying that during the last summer he had rashes on his whole body. He also applied the leper-ointment, and with this he drove the rashes back into his body. Recently he also was examined by a noble barber-surgeon, who explicitly acquainted me with the fact that the above-mentioned Martin, a subject [under the powers] of my office, was infected with the mentioned pestilence inside his body, particularly in his mouth and other body parts. ${ }^{47}$

So the bailiff wrote to the medical faculty. Villagers' claims were taken seriously enough to set in motion, repeatedly, a whole apparatus of observation, evaluation, communication, and intervention spread across several centers of knowledge and governance as far as a hundred kilometers apart. The villagers of Eutingen were not to be overruled by the Collegium Medicum of Strasbourg, their opinion was supported by that of a "noble" barber-surgeon in the regional administrative center, and the Habsburg representative did not hesitate to refer the case to a medical faculty and Europe's leading dermatological authority. Identifying (plausibly) leprosy or the French Pox may seem not much to expect of villagers, until we recall that the whole system of official inspection, of Schau, which operated for several centuries throughout the Holy Roman Empire and beyond, was built up around the difficulty of making exactly these empirically based judgments. ${ }^{48}$ In this system, local communities in effect practiced Schau before the experts did. ${ }^{49}$ Like a practitioner watching his patient, the people of Naff's hamlet even monitored therapeutic outcomes - the effect of an ointment - and explained them. Their explanation was not "popular." In explaining the perceived treatment outcome as an act of driving noxious matter back into the body, these villagers represented the disease in the same way that physicians and surgeons did. ${ }^{51}$

Questions of community boundaries and security, of purity and danger, were not the only kind to be addressed through common ways of observing and judging bodies and their environments and evaluating their histories. Questions of the ability to reproduce and to produce - of marriage, work, and family economy - were another. These have been studied mainly as part of history of the body and power. ${ }^{52}$ Yet they can also be understood as belonging to the history of empiricism broadly conceived. 
In 1605 in the city of Ulm, a recently betrothed dyer named Andreas Heffelin had to appear before a jury of seven. It was a jury of barbers: the officially sworn master barbers and barber-surgeons of Ulm. This jury not only questioned and listened; it inspected. The object of inspection was Heffelin himself - his whole body and especially his left arm. Heffelin was being examined to settle the question of whether the marriage contract could be annulled. His bodily condition would be decisive for this question. Yet it had already been evaluated - by "lay" people, namely, his bride and father-in-law, though too late to have avoided contracting marriage in the first place. They presented evidence to the Ulm marriage tribunal that Heffelin might not be able to work at his trade and thus support his wife and family to be, and indeed that he might not be fit to make a family at all, in short, to produce and reproduce. On close inspection in the familial milieu, he appeared to have a problem with his left arm, and its condition suggested to the family that he could be afflicted with the French Pox, a diagnostic judgment which, as we have seen, was by no means obvious, even to physicians and surgeons. ${ }^{53}$

The family's judgment that Heffelin might have the French Pox was cogent and well founded enough that it took the jury of seven artisanal masters considerable empirical work observational and history-taking - and knowledge of similar cases to construct an alternative explanation: that the damage in his left arm resulted from maltreatment of a malignant ulcer (Geschwer) that had affected the bone. Likewise, the family's prognosis for Heffelin's working life could only be countered persuasively by a carefully worked out and circumspect alternative one: that more bone fragments might break from that damage but that in the end a permanent cure was likely. ${ }^{54}$

Thus Schau, the general empirical evaluative practice on which such a case turned, was an activity of perpetuating a community's welfare as much in terms of its familial and economic reproduction (Heffelin and dyer families) as in terms of its boundaries and security (Naff and his hamlet). ${ }^{55}$ What was being observed and evaluated was at once a medically defined physical condition (ulcer, maltreatment, pox, cure) and a socially defined physical condition (productive and reproductive capacity in a given type of community and economy, ability to exercise a particular trade). A turn of phrase clinches this identity of the medical and surgical and the familial and economic: the appeal to the marriage tribunal was articulated as a request to allow return of unsatisfactory goods: ist die Braut, wie auch iren Vattern, ein Reukauff ankomen. ${ }^{56}$ The term Reukauff - literally regretted purchase - denoted the right to withdraw from a sales contract. A jury consisting of guild masters was hardly out of place in carrying out a procedure representable as quality control of goods, a typical function of guilds in their capacity of 
evaluation, ${ }^{57}$ which was the role in which we find these barber-surgeons acting here as observerjudges rather than healers.

Judgment or testimony by medically trained men is thus not necessarily best understood as "medical expertise." The same can be seen in cases of criminal law, such as the trial of Martin Rode. Official town physician (Stadtarzt) Dr. Stock testified that he saw Anna when she had "lost her senses" before she died, but that she did not die from beating. The injury to her head was no Causa necessaria. Her own bile and rage (Bilis vnd der Zoren) caused her illness. Had Anna died from the injury, he added, she would have shown "epilepsia". ${ }^{59}$ It looks as though Dr. Stock is applying the knowledge of the learned physician. Yet before Dr. Stock testified, the court had already heard the same reasoning - from the defense lawyer: notably, the either/or structure of "died because of the illness and not because of the beating" and the argument that Anna's symptoms when she "lost her senses" were not those of injury to the head. These ways of accounting for death in cases featuring variables like lapse of time between injury and death made up a legal literature going back to the 13th century, including case reports in the form of jurists' consilia. ${ }^{60}$

The formulae of reasoning and argument used in such cases were not empty. They were a form of what is all too crudely called knowledge and can more precisely be called generalisations from analogous situations, yet in the form of rational practices rather than theories, and created through the cumulative effect of many cases rather than acts of innovation. Thus the formulae were not dead either. They lived through configurations of society and polity and the observed physical world. "Causa non necessaria" was neither medical nor legal knowledge. It expressed a configuration of exigency (the court needed a yes or no) and responsibility (Stock was the official town doctor, charged with forensic duties) and uncertainty (over a week passed between injury and death and observational evidence was varied). The learned physician, in short, was equally a non-medical participant.

And, vice versa, the housewives were as much medical as lay participants.

"Whether the cranium and the dura and pia mater had been damaged by the beating"? This, as we saw at the outset of this paper, was one of the dozens of questions put by the judge to barber-surgeons, physicians, and - probably minus the Latin - to housewives. When Katharina Hansenn, housewife, answered to the effect that she observed no head injury "and indeed [the] only [marks] Anna had [were] small blue spots at both knees," she was not reporting what she happened to glimpse in the crowded aftermath of some violent incident. ${ }^{61}$ She answered as an observer on a par with the medical men and as a witness to the official postmortem. For late medieval Spain, Debra Blumenthal plausibly explains the continuing role and authority of 
women without office testifying in juridical trials on a par with medical men in office because householding women were de facto "experts" through their domestic medical experience. ${ }^{62}$ Our case studies support this explanation, but it goes only so far. Housewife attendance at Anna's postmortem shows a continuum of domestic and public life. ${ }^{63}$

As to explaining death and thus resolving the matter that busied Frankfurt almost weekly for much of 1551, the most cogent and evidence-based account did not come from the physicians or surgeons, but from the housewives and, reportedly, from the deceased herself.

"Whether the witness," Highest Justice Mohr asked Hausfrau Hansenn as he had asked Stadtarzt Stock, "holds that the fatal illness phrenesie first began on the 7th day after the beating and [that the deceased] had suffered long before from an internal illness such that she died because of the illness and not because of the beating"? ${ }^{64}$ Hansenn answered essentially yes. She believed Anna "would not have died from the beating had illness not already been present beforehand." And what was this pre-existing condition? Ever since she had had a stillbirth, she had not ceased to "have bodily complaints." Unlike the testimony by the barber-surgeons and physicians, this explanation accounted for major signs observed at the official autopsy. Hansen ascribed the large black area on Anna's back (which she saw only after the death) to the great heat of the illness. ${ }^{65}$ On the testimony of the surgeons and the physicians, these appearances remained apparently significant yet of uncertain meaning.

Evidence of this internal condition was attributed to Anna herself. Anna's relative the apothecary's wife, last of the 21 witnesses, spoke for her (in answering the fourth question to the 40th Article, to be precise): "Yes, he did beat me, but such beating harms me not at all, if only the lump were not in my body, which I worry will carry me off and kill me. Then, my Martin and I are content in our relationship and one." 66 We will never know for sure whether Anna really felt and said what others said she did, but we do know that Martin was acquitted and that together with the testimony of her speakers - Anna's was the most evidence-encompassing account of her own death. Judge and jurymen could acquit with more confidence on the medical account given by Housewife Hansenn and Apothecary's Housewife Wörner Winneck than that given by Stadtarzt Dr. Stock, not to mention the barber-surgeons who all said they couldn't say. It is a fitting conclusion at this point in the story of shared empirical rational practices that the most robust causal explanation constructed in the trial - most robust because it accounted for more observations and testimony, medical or otherwise, than any other - was told as patient narrative.

\section{Difference and Commonality}


It may seem at this point that we have romanticised a past of knowledge shared by all and evaluations accepted by everyone. Yet, as emphasized from the outset, in this history of common knowing, there were differences among groups participating in inspections, inquiries, trials. In pursuing these differences, however, we will not follow the literature on the rise of medical forensic expertise. ${ }^{67}$ Nor will we focus on clash or cooperation between different medical experts and between "expert" and "lay" witnesses, nor on their relative authority and how this changed historically. ${ }^{68}$ Instead, in any given case, we show momenta of differentiation and dedifferentiation, a term preferable to leveling, which denotes mainly the status of claims to knowledge or expertise. ${ }^{69}$

On September 10, 1624, the provost of the Imperial Abbey of Wettenhausen wrote to the Lutheran mayor and councillors of Ulm requesting an evaluation (guttachten) by the sworn surgeons or the physicians in office regarding the death of one of his subjects, Margarete N. The jurymen master barber-surgeons received two letters and the "instruction to find what is right."70 After considering the written accounts of Margarete N.'s fate, they decided it would be necessary to interrogate the late woman's husband and the practitioners involved.

It had all begun when Margarete visited a barber who agreed to let her blood, a situation of typical patient-practitioner commonality. All later accounts agree that she began to feel pain after this practitioner, "the resident village-barber" Hans Spitz, stopped the bleeding by applying a pressure dressing. ${ }^{71}$ That same Saturday afternoon, according to her husband's testimony, Margarete demanded help from Spitz, but he made her wait till Sunday evening. In the account sent to the Ulm masters of surgery, Barber Spitz knew no remedy (remedium) for this pain and sought a nearby colleague's evaluation and recommendation (gutachtung). This second barber suggested warm wine dressings. Spitz had them applied to Margarete's arm several times that evening. When the pain only grew worse, Margarete consulted a third barber and for three days used a remedy he recommended - in vain. Thereafter, her husband consulted Spitz again, which was no help. On day eight - earlier, in Spitz's version - Margarete removed the bandage and walked about three kilometres to see a fourth barber. The following day, she traveled some eleven kilometres, still unbandaged, to see a fifth barber, named Jelin. He "inspected" her wound and declared that gangrene (der kalte Brand) had taken hold in her hand. In the presence of "two judges" (in bey sein zweier Richter), this diagnosis was confirmed on day twelve when fingernails and skin could be removed without causing pain. Jelin predicted she would die and offered amputation as final resort. On day eighteen, Jelin in cooperation with his father, Surgery Master Matheis Jelin, who traveled more than twenty kilometres to operate, amputated Margarete's lower arm. This, too, was in vain. She died thirteen days later. Right through the 
final stage, when Jelin diagnosed fatal gangrene and offered to amputate, Margarete typifies the self-directed if desperate patient, seeking help as and where she saw fit, from qualified barbersurgeons whose capacity to know what was wrong and what to do was not fundamentally different from hers, yet who at the same time inspected and evaluated. In short: this is a story of momenta of both commonality of knowing and differentiation of knowing into procedures.

These contrary momenta continued during the inquiry. The provost wanted to know which of the barbers who accused each other was to blame for the death of Margarete, which barber would have to answer to the husband's monetary damage claims, and which practitioner would have to be paid by whom. The master jurymen of surgery had to judge not only whether Spitz, the first barber, or one of his colleagues, was the "causer of such an irreversible event," but also whether one of them should be banned from the surgical art. ${ }^{72}$ In their report, they approved the various barbers' remedies as conforming to the art and remarked that Jelin, the amputator, had not been accused. They concluded by explaining the course of the illness and effectively blaming the patient: removing the bandages prevented recovery. This was, in effect, to close ranks in a situation that threatened to undermine the legitimacy of an entire region's official surgical practice. Humoral theory supported this account: removing the bandages had allowed moisture into the limb; thus deprived of its natural warmth, the limb died of gangrene. Not theory, but documented experience supported the patient's account: she removed bandages and, in the most active possible way, sought further help because she knew by experience that the dressings were not lessening the pain and that she needed other remedies. The jury of masters knew by theory that removing the bandages led to fatal gangrene. The jurymen masters' position was fraught enough that they sought legitimating approval for it from the Ulm town physician, which they received. ${ }^{73}$ Margarete's position, represented by her husband's testimony, was also supported: by the provost. He suspected that one or more barbers, not the patient, were to blame, at very least because they accused each other. Thus what differentiated in the end was not some obvious - or blurred - divide between lay and expert or professional knowledge and practice. What differentiated knowledge of what happened to Margarete's arm, and why, into two accounts was referral of the case to an outside adjudicator. And yet the judgment of the outside experts dedifferentiated: the sworn masters explained the effects of bandage removal by reference not to their special surgical knowledge, but to widely shared humoral theory.

Differentiation and dedifferentiation were no less subtle yet significant in juridical cases, which, according to standard stories of the rise of expert medical testimony in the 16th century and earlier, ought to have been considerably more straightforwardly differentiated and expertled. We can see this by returning to the case of Clauß Guntram in 1517, whose well-informed 
defense against charges of having killed another man was presented in Section 1 above. Guntram named a barber-surgeon as witness, Master Hans Albrecht. Albrecht testified that he "examined" the wound inflicted by Guntram the day after. By measuring with his instrument, he "found" that the stab ended at the rib. ${ }^{74}$ This was a standard procedure, detailed in contemporary books of surgery, for therapeutic and forensic prognosis. A wound ending already at the rib was considered a minor injury. ${ }^{75}$ In addition to basing his testimony on this manual procedure and know-how, the master alluded to his special knowledge with the remark that he applied a bandage as appropriate for such wounds (wie sich Zu solichenn wunden geburt). Moreover, he presented himself as a master of his art by stating that he "healed" the man in less than three weeks. Finally, Albrecht presented prognosis as part of his special knowing by recounting how he cautioned the convalescent victim, Genßhenn, against hard work for a quarter of a year to allow full recovery. ${ }^{76}$ These are the ways in which differentiation of knowing occurred in this case.

The dedifferentiation of knowing in Guntram's trial occurred twofold. First, the barbersurgeon testified in response to questions that were put to all nine witnesses, exactly as we saw in the Rode case. If medical qualification and experience singled him out from the others, the procedure and context of testimony grouped him right back with them. Second, the barbersurgeon's statements were no more exact in description or relevant in explanation than those of the other witnesses. Two neighbours recounted visiting the victim Genßhenn while he was bedridden for the second time, that is, after his alleged recovery. They inquired into the nature of his sickness and reported patient narrative just as a doctor might have done: Genßhenn described the feeling of a "lump on his heart." They also presented evidence against the lethality of the stabbing: the victim had let them "see" that his scar was closed and himself did not attribute his second period of illness to the stabbing. ${ }^{77}$ Even Pastor Conradt vonn Steinhem, who visited bedridden Genßhenn to hear confession and administer the sacraments, testified that "outside of confession" he had asked "how the wound was doing" and received Genßhenn's answer: "it is healed." ${ }^{78}$ And the barber-surgeon? He attested recovery by recounting from everyday life: that some weeks after the stabbing he and Genßhenn had gone to market together to buy pigs, walked back, and shared a meal. The evidence he gave to account for Genßhenn's fatal illness following recovery was as much everyday as medical: the convalescent had failed to follow surgeon's orders and had over-taxed his body too soon through hard work, for which Albrecht was able to cite the late patient's account: Genßhenn had reported that he had felt a "cracking" in his body when lifting timber. ${ }^{79}$ If it was obvious that one called the barber-surgeon and not the pastor or 
the neighbor to treat a stab wound, they were virtually all of a piece in giving - creating evidence.

It might be objected that we have been able to illustrate these processes of differentiation and dedifferentiation happening within a single case because we have chosen one from early in the 16th century, before the rise of expert witnessing as formalized in new criminal law. Yet the same dynamics of differentiation and commonality of knowing can be found in trials such as the Rode case of 1551 - after a half century of legal reform that included the Carolina, supposed watershed in the rise of expert medical witnessing, and with testimony by two official town doctors and six sworn barber-surgeons. ${ }^{80}$

These dynamics began at the sickbed, in observational practice before Anna died. Anna's foster-mother, Anna Buchens, came when she heard about the beating and was asked to attend at the bedside. Herself a midwife, she cared for Anna to the end. Despite her expertise, however, she called for the official town doctor, Johann Stock, to examine the sick, using the official term besichtigen. This was to differentiate official observation not only from everyday observation of the body, but from experienced - expert - observation of the body, a differentiation we explore below in the conclusion. This differentiating momentum in the case began at about the same time as its opposite: when Rode's mother and Anna's sister also came to examine her: "Annen zubesichtigen." ${ }^{\prime 1}$ They and other "lay" female witnesses would later be able to provide more detailed explanations and observations than Dr. Stock. Anna drank too much - beer, wine and huge quantities of mineral water; she had had constant health complaints since a stillbirth; they had observed no signs of serious injury or severe illness after the violent encounter with her husband, nor vomiting or bleeding. Moreover, they would report signs of other sickness, such as fever, confirm that she had fallen down the cellar stairs, and testify that Anna had been able to work and talk sensibly after the beating. ${ }^{82}$ These, then, were the momenta of differentiation and dedifferentiation of knowers - official medical expert and "lay" female witness - before Anna died.

The dynamic continued after her death. Six barber-surgeons participated in examining the body and dissecting its visible wounds. They found a bruise over the left eye and black and blue areas on the back. Dissection and probing of these revealed coagulated blood and no bone breakage behind the bruise. Following examination, the six barber-surgeons deliberated and reported their conclusions collectively at the town hall. They concluded that they could not decide whether Anna died from beating, falling down, or another sickness. ${ }^{83}$ No one else was invited into this procedure - though, as we know, others attended. 
Yet as soon as the case file began to take shape, this differentiation of expert official observation from other observation began to dissolve. The barber-surgeons' postmortem report to the council was not copied into the file. It sat in an official book in the town hall: never even quoted (though referred to) in the more than 150 manuscript pages of the Rode proceedings preserved today. Thus there was nothing written to prevent the institution of oral testimony from having the same levelling effect we saw in the Guntram trial 35 years before. In this way, the central practice of inquisition - questioning - had the opposite effect from the one usually attributed to it with regard to the rise of expertise. Inquisition broke up the collective unanimous expert opinion of the sworn master surgeons in their official deposition to the city council. Surgeons and physicians were individually questioned and their responses recorded as individuals alongside and undistinguished from all other individual witnesses, notably the housewives. And the answers given by all were usually comparable with one another in terms of descriptive and explanatory content. ${ }^{84}$

The hearings did more.

“Did you assist in anatomizing Anna after her death?” Highest Justice Mohr wanted to know - again, asking the housewives as well as each of the six sworn surgeons and official town physicians. Clearly, he assumed that the housewives could perfectly well have assisted in the official autopsy, but that is not specifically the point here. "No, I did not help," Anna Housewife of Johann von Buchens answered, "but once the barber-surgeons had cut her open I saw that there had been black and blue coagulated blood (geliebertt blut) in the bruises and spots (mälern), but whence this bleeding came is unknown to me." ${ }^{85}$ To be sure, the mayor did not ask the housewives to join the surgeons in carrying out the postmortem inspection. But Anna Buchens observed the body as carefully as the barber-surgeons did and testified with approximately the same level of descriptive detail. Yet this, too, is not specifically the point here. The point is rather one of mechanisms of dedifferentiation: the witness hearings retroactively transformed specialist official inspection, the "Besichtigung" ordered by the mayor, into knowing in common. This is especially remarkable because that event had been officially closed, signed and sealed in one of the city's books.

\section{Conclusion}

Commonality in diversity is the main finding of this study. To see this, rather than difference and dialogue, required setting aside categories like expert and lay to examine the practices of all concerned. Historians have come to examine a range of witnesses and other participants in early modern criminal and witch trials, but this may be the first study, regarding any historical time 
and place, of the knowledge roles of the full range of participants in a much wider variety of public cases. ${ }^{86}$ Hidden in the diversity of situations in these cases, whose protagonists usually belong to separate histories, is a set of common practices: observing, inspecting, and reporting; weighing of diverse evidence and certifying or judging on that basis; reasoning to causal accounts of complex events in the physical and human world. The cases were diverse in at least four ways: (1) participation, (2) situation and applicable rules, (3) evaluating institutions, (4) polity, which ranged from village to city to empire, from self-government of sovereign citystates to local government in the Habsburg Empire (with consultation of an institution in a neighboring territorial-administrative state) to government of a small principality by the provost of an abbey (with consultation of an institution in a confessionally opposite state). These four kinds of diversity show the depth and extent of the commonality of knowing practices.

Expertise does not need "rethinking." ${ }^{\circ 7}$ It needs a rest. Thinking in terms of expertise blinds us to common knowledge. Modern can learn from premodern here. Historical studies of law and science, or law and medicine, usually adopt the language of expertise and the category of expert witness. This disinvites investigation of all participants as knowers. The focus remains on men of science and physicians as experts. ${ }^{88}$ Historians of premodern medicine have diversified this picture by studying a variety of experts in trials - legal as well as medical, midwives as well as surgeons and physicians. Yet it remains a picture of difference and interaction. ${ }^{89}$ Would setting aside categories like expert and lay and studying all participants as knowers, as we have done, yield similar results for more recent times, showing shared empirical rationality? At very least, the invention of the concept of lay expertise and controversy over these categories in social studies of recent science, technology, and medicine suggest it might. ${ }^{90}$ Many of the situations of uncertainty, disagreement, or accusation studied in this paper have modern counterparts. ${ }^{91}$ This is not to preach continuity over change. The history between then and now may conform neither to lines of continuity nor to lines of change, like the "rise" of special knowledges and occupations, but comprise multiple trajectories of emergence and disappearance and re-emergence of knowing in common. Only then will a general history of expertise become possible, a history that does not presume what it ought to explain and that neither expands into the history of every activity in which human beings build up special experience nor contracts into the history of competing claims to such experience.

The problem is not that historical studies have been insufficiently constructionist or indeed historical about expertise. Showing how expertise was contested and constructed leaves intact the focus on special knowledge and claims to it, hence on different groups and their status and rivalry. The very idea of expertise is the problem. It is limiting because it necessarily means 
special (everyone cannot be the expert ${ }^{92}$ ), a limitation not lifted by the discovery that there have also been "lay" experts, having their own knowledge and gaining authority or opportunity to pronounce on public matters in certain times and places. Specialty there was, of course, and interaction but also - and that has been the thesis of the foregoing paper - shared practices of knowing. The point is not a wider picture of who knew, but a different picture of what knowing was and, ultimately, how and why it occurred. This paper is not a call for inclusiveness as such. An account of knowledge society - 16th century or 20th - which included everyone according to what made each group special would still miss the point.

This opens a new problem: If knowledge was so common, then why was the testimony of physicians and surgeons needed at all? One way of tackling this concluding question would be to ask what determined why cases were decided in one way or the other. That might show the relative efficacy of diverse participants' descriptions and explanations. Yet for any given case, this question can seldom be answered, as the historian never fully knows what went on orally behind and around the documents nor what documents may be missing. Taken in the aggregate, however, large numbers of cases tend to show that (1) the social status of the accused was less important in trial outcomes than we might expect, and (2) social connectedness was crucial, that is, how many people you could mobilize on your behalf (as in the case of Martin Rode), or not (as in the case of Martin Naff). Recent research shows that even trials for crimes punishable by death were usually integrative and oriented toward consensus. For these could destabilize the polity. ${ }^{93}$ The perpetuation of polities based largely on negotiated consensus depended on involving as many people as possible in that consensus. The language of this perpetuation was that of peace, as in Stadtfrieden or Landfrieden. ${ }^{94}$ No one could be left out of the peace, or at least that was the ideal approximated as much as possible in practice. Such a system seems to have little or no place for specially experienced knowers.

In fact it did, but not as specialists. To leave no one out of the peace meant to include (1) all who were implicated through social ties, whether of kinship, neighborhood, or household, and (2) all who were responsible through public office for the area of social and material life in which the disagreement, uncertainty, or possible injustice occurred. This is where the doctors and surgeons come in. Responsibility more than specialty: that, oddly enough by our standards and histories of expertise, is how to understand their involvement. Doctors and barber-surgeons in public office testified, inspected, reported, certified, or recommended decisions not as unique or superior knowers but as those on duty in matters of health and disease, injury and death, purity and danger. Their oaths of office made them responsible for bodily aspects of community welfare. ${ }^{95}$ That did not exclude the possibility that others had comparable knowledge and 
experience and that they, too, would contribute, as can be seen in all of the proceedings examined in this paper. These cases suggest that all relevant knower groups had to be represented in the process so that consensus and peace could result. Thus physicians and surgeons, who appear to our eyes as expert witnesses and evaluators, in fact belonged to a highly knowledgeable consensus-building society rather than an expert-governed lay one.

Amidst the commonality of knowing, there was one difference between those involved through social ties and those involved through office. This was the difference between being party and not being party to the events and persons in question. Office-holding physicians and surgeons typically swore an oath of impartiality. ${ }^{96}$ They were supposed to testify or certify or evaluate knowledgeably without being party - literally without having had a part in events, from outside the situation of disagreement, uncertainty, or possible wrong-doing and the web of social relations to which it belonged. ${ }^{97}$ To act justly, office holders had to be independent, uninvolved. Yet this made them at the same time dependent, on those who were involved. Knowledgeable parties were as vital to proceedings as impartial knowers - not despite but because they were party. They knew events, contexts, bodies far more intimately than the office-holding doctors and surgeons could do, or could do alone. And we know from all of the cases considered here that this local knowledge meant not only reporting what one saw, but also explaining and judging. Impartial expertise did not trump local expertise, or personally referred testimony. Otherwise in the Naff case, for instance, inspection and certification by the far-off Strasbourg medical collegium would have secured the old soldier's status against villagers' continuing observations and suspicions. Exactly how implicated knowing and impartial knowing played out in testimony, evaluation, and the resolution or reopening of cases (and how this changed in the period under study) remains a question for further research. But it is beside the point here. Whatever such research might show, it is a fitting conclusion to this study of shared empirical rational practice that the knowledge of the two main kinds of participant in public cases impartial and party - was not only common but complementary, indeed mutually dependent, in the one way in which they, necessarily, differed.

\footnotetext{
- This paper is a publication of the research project "Ways of Writing: How Physicians Know, 1550-1950," funded by the European Research Council. We thank Alix Cooper, Angela Creager, Lorraine Daston, Alexa Geisthövel, Volker Hess, David Sabean, and two anonymous Isis referees for comments.

${ }^{1}$ For the study of knowledge practices at its most expansive, see Christian Jacob, ed., Lieux de savoir, 2 vols. (Paris: Albin Michel, 2007-2011), 1: Espaces et communautés (1,282 pp.) and 2: Les mains de l'intellecte (992 pp.). Space permits citing only selected recent early modern work. Artisans: Ursula Klein, ed., Artisanal-Scientific Experts in Eighteenth-Century France and Germany, special issue of Annals of Science 69, no. 1 (2012); Pamela Long,
} 
Artisan/Practitioners and the Rise of the New Sciences, 1400-1600. (Corvallis: Oregon State University Press, 2011); Pamela H. Smith, The Body of the Artisan: Art and Experience in the Scientific Revolution (Chicago: Univ. of Chicago Press, 2004). Women's chemical and medical knowledge: Alisha Rankin, Panaceia's Daughters: Noblewomen as Healers in Early Modern Germany (Chicago: Univ. of Chicago Press, 2013); women's anatomical knowledge: Katharine Park, Secrets of Women: Gender, Generation, and the Origins of Human Dissection (New York: Zone Books, 2006); see also Sharon T. Strocchia, ed., Women and Healthcare in Early Modern Europe, special issue of Renaissance Studies 28: 4 (2014). Merchants: Pamela H. Smith and Paula Findlen, eds., Merchants and Marvels: Commerce, Science and Arts in Early Modern Europe (New York and London: Routledge, 2002). States and administrators: Eric H. Ash, ed. Expertise: Practical Knowledge and the Early Modern State (Osiris 25; Chicago: University of Chicago Press, 2010); Peter Becker and William Clark, eds., Little Tools of Knowledge: Historical Essays on Academic and Bureaucratic Practices (Ann Arbor: Univ. of Michigan Press, 2001). For the place of some of these expansions in the currently standard overview of the history of science: Katherine Park and Lorraine Daston, eds. The Cambridge History of Science, Volume 3: Early Modern Science (Cambridge: Cambridge University Press, 2006), chs. 7-9: Londa Schiebinger, "Women of Natural Knowledge," 192-205; William Eamon, "Markets, Piazzas, and Villages," 206-223; Alix Cooper, "Homes and Households," 224-237.

2 Peter Galison and David J. Stump, eds., The Disunity of Science: Boundaries, Contexts, and Power (Stanford: Stanford University Press, 1996); John V. Pickstone, Ways of Knowing: A New History of Science, Technology, and Medicine (Chicago: University of Chicago Press, 2001). Visual and textual practices: Sachiko Kusukawa, Picturing the Book of Nature: Image, Text, and Argument in Sixteenth-Century Human Anatomy and Medical Botany. (Chicago: University of Chicago Press, 2012). Observational and descriptive practices: Brian W. Ogilvie, The Art of Describing: Natural History in Renaissance Europe (Chicago: University of Chicago Press, 2006); Gianna Pomata and Nancy G. Siraisi, eds., Historia: Empiricism and Erudition in Early Modern Europe (Cambridge, Mass: MIT Press, 2005); Lorraine Daston and Elizabeth Lunbeck, eds., Histories of Scientific Observation (Chicago: University of Chicago Press, 2011).

Information: Arndt Brendecke, Markus Friedrich und Susanne Friedrich, eds., Information in der frühen Neuzeit: Status, Bestände, Strategien (Berlin: LIT Verlag, 2008); Ann Blair, Too Much to Know: Managing Scholarly Information before the Modern Age. (New Haven: Yale University Press: 2010). Note-taking in diverse domains: Ann Blair and Richard Yeo, eds., Note-Taking in Early Modern Europe, special issue of Intellectual History Revue, 20:3 (2010), 301-433. Transfer and dialogue: Kaspar von Greyerz, Silvia Flubacher, and Philipp Senn, eds., Wissenschaftsgeschichte und Geschichte des Wissens im Dialog - Connecting Science and Knowledge (Göttingen: V \& R unipress, 2013); Peter Howlett and Mary S. Morgan, eds., How Well Do Facts Travel? The Dissemination of Reliable Knowledge (Cambridge: Cambridge University Press, 2011); James A. Secord, "Knowledge in Transit," Isis, 2004, 95:654-672. ${ }^{3}$ In the conclusion below, we engage briefly with social studies of recent science and expertise. Probably the most in-depth yet long-term historical study of expertise, government, and the public is now the pair of volumes by Emma C. Spary: Eating the Enlightenment: Food and the Sciences in Paris, 1670-1760 (Chicago: University of Chicago Press, 2012); Feeding France: New Sciences of Food, 1760-1815 (Cambridge: Cambridge University Press, 2014). Overview for law and medicine: Katherine D. Watson, Forensic Medicine in Western Society (New York: Routledge, 2011), chs. 2-3; study of expert-expert and expert-lay interaction has been developed by Silvia de Renzi, "Witnesses of the body: medico-legal cases in seventeenth-century Rome," Stud. Hist. Phil. Sci., 2002, 33:219-242; Silvia de Renzi, "The Risks of Childbirth: Physicians, Finance, and Women's Deaths in the Law Courts of Seventeenth-Century Rome," Bulletin of the History of Medicine 84 (2010), 549-77; Cathy McClive, "Blood and Expertise: The Trials of the 
Female Medical Expert in the Ancien-Régime Courtroom," Bulletin of the History of Medicine 82, 2008, 86-108; Debra Blumenthal, "Domestic medicine: slaves, servants and female medical expertise in late medieval Valencia," Renaissance Studies 28, 2014, 515-32. On early modern expertise, see generally Ash, ed., Expertise; and the graduate research program

"Expertenkulturen des 12. bis 18. Jahrhunderts": https://www.uni-goettingen.de/de/100282.html; Hedwig Röckelein and Udo Friedrich, eds., Experten der Vormoderne zwischen Wissen und Erfahrung, special issue of Das Mittelalter 17:2 (Berlin: Akademie-Verlag, 2012); Björn Reich, Frank Rexroth, and Matthias Roick, eds., Wissen, massgeschneidert: Experten und Expertenkulturen im Europa der Vormoderne (Historische Zeitschrift, Beiheft n.s. 57; Munich: Oldenbourg Verlag, 2012); and taking a long view of experts and expertise in criminal justice: Alexander Kästner and Sylvia Kesper-Biermann, eds., Experten und Expertenwissen in der Strafjustiz von der Frühen Neuzeit bis zur Moderne (Leipzig: Meine Verlag, 2008).

${ }^{4}$ Institut für Stadtgeschichte, Frankfurt am Main, Städtisches Archiv, Criminalia (hereafter: IfS Crim.) 25, f. 24v (ob die Hirnschall vnnd Dura vnnd pia Mater durch das schlagen entgenzet worden) and f. $44 \mathrm{v}$.

${ }^{5}$ IfS Crim. 25, cover page and ff. 1-6, 16-17, 30, 51-55, 82v, verdict. In the early modern Holy Roman Empire, the office of Highest Worldly Justice (Oberster Weltlicher Richter) was that of prosecutor and conductor of juridical proceedings, not judge in the modern sense. In 16thcentury Frankfurt, however, this office was held by the same person who held the office of sheriff (Schultheiß), so Mohr also judged as a member of the jury (Schultheiß und Scheffen). See Anja Johann, Kontrolle mit Konsens: Sozialdisziplinierung in der Reichsstadt Frankfurt am Main im 16. Jahrhundert (Frankfurt am Main: Kramer, 2001), 69-71, 241-4.

${ }^{6}$ In the hearings, he would have phrased questions differently according to witnesses' educational level, notably by substituting vernacular for Latin terms. On redaction of oral proceedings into written protocols, see David Warren Sabean, "Peasant Voices and Bureaucratic Texts: Narrative Structure in Early Modern German Protocols" in Little Tools, ed. Becker and Clark, 67-93.

${ }^{7}$ On these sources and institutions, see Johann, Kontrolle mit Konsens; Annemarie Kinzelbach, "Erudite and Honoured Artisans? Performers of Body Care and Surgery in Early Modern German Towns," Social History of Medicine 27 (2014): 668-88; Wolfgang Nachtmann, Die Gerichtsmedizinischen Gutachten der Tübinger Medizinischen Fakultät (1600-1923), Dissertation, Medical Faculty, Tübingen 1978; we draw additional examples from published records of the Leipzig medical faculty and from the city archives of Nördlingen and Überlingen; see notes $<34$ and $49>$ below.

${ }^{8}$ Laura Gowing, Common Bodies: Women, Touch, and Power in Seventeenth-Century England (New Haven: Yale University Press, 2003); McClive, "Blood and Expertise."

${ }^{9}$ On medical pluralism: Mary Lindemann, Medicine and Society in Early Modern Europe (Cambridge: Cambridge University Press, 1999); David Gentilcore, Healers and Healing in Early Modern Italy (Manchester: Manchester University Press, 1998); and recently Robert Jütte, ed., Medical pluralism: past-present-future (Stuttgart: Franz Steiner Verlag, 2013), in debate with the idea of a "unitarian medical world" in Laurence W. B. Brockliss and Colin Jones, The Medical World of Early Modern France (Oxford: Clarendon, 1997), 237.

${ }^{10}$ Barbara Duden, The Woman beneath the Skin: A Doctor's Patients in Eighteenth-Century Germany (Cambridge, Mass.: Harvard University Press, 1991); Gowing, Common Bodies; Claudia Stein, "The Meaning of Signs: Diagnosing the French Pox in Early Modern Augsburg," Bulletin of the History of Medicine 80 (2007), 617-48, on 621-23.

${ }^{11}$ Peter Burke, A Social History of Knowledge: From Gutenberg to Diderot (Cambridge: Polity Press, 2000), ch. 1; historiography of witch trials now explores shared concepts and plurality of knowledge: Thomas Robisheaux, The Last Witch of Langenburg: Murder in a German Village 
(New York: W.W. Norton, 2009); Ulinka Rublack, The Astronomer and the Witch: Johannes Kepler's Fight for his Mother (Oxford: Oxford University Press, 2015).

${ }^{12}$ Historians have noted but not yet studied and drawn conclusions from the "extremely wide range of issues" dealt with by early modern physicians in their medico-legal capacity: De Renzi, "Witnesses of the Body," 226; Hamlin, "Forensic Cultures," 7; Catherine Crawford, "Medicine and the Law" in W. F. Bynum and R. Porter, eds., Companion encyclopedia of the history of medicine, 2 vols. (London: Routledge, 1994), vol. 2, 1619-40, on 1624.

${ }^{13}$ Summary of such processes has therefore been kept to a minimum in the case studies.

${ }^{14}$ Here we build on recent research showing continuum in practice between the formally distinct domains of Recht and Policey in both free cities and territorial states. Detailed studies include: Johann, Kontrolle mit Konsens, esp. 157-253; Karl Härter, Policey und Strafjustiz in Kurmainz: Gesetzgebung, Normdurchsetzung und Sozialkontrolle im frühneuzeitlichen Territorialstaat. 2 vols. (Frankfurt am Main: Klostermann, 2005).

${ }^{15}$ Recent overview of medieval and early modern medical testimony: Watson, Forensic Medicine, chs. 2-3; on non-medical expert witnessing before 1800: Tal Golan, Laws of Men and Laws of Nature: The History of Scientific Expert Testimony in England and America (Cambridge, Mass.: Harvard University Press, 2004), ch. 1.

${ }^{16}$ Recent contributions to the large literature on early modern patients and on popular and domestic medicine include Andrew Wear, "Popular Medicine and the New Science in England: Cross Roads or Merging Lanes?" in Wissenschaftsgeschichte, ed. Greyerz, Flubacher, and Senn, 61-83; Michael Stolberg, "Learning from the Common Folks: Academic Physicians and Medical Lay Culture in the Sixteenth Century," Social History of Medicine 27 (2014), 649-67; see also Special Issue: Women, Health, and Healing in Early Modern Europe, Bulletin of the History of Medicine, 2008, 82/1.

${ }^{17}$ These findings overlap with those on "state-building from below" across Europe. Three landmark volumes are Rudolf Schlögl, ed., Interaktion und Herrschaft: die Politik der frühneuzeitlichen Stadt (Konstanz: UVK Verlagsgesellschaft, 2004); André Holenstein, Wims Blokmans, Jon Mathieu, eds., Empowering Interactions: Political Culture and the Emergence of the State in Europe, 1300-1900 (Farnham: Ashgate 2009); Jason P. Coy, Benjamin Marschke, David W. Sabean, eds., The Holy Roman Empire, Reconsidered (New York: Berghahn 2010).

${ }^{18}$ See recently Christopher Hamlin, "Forensic Cultures in Historical Perspective: Technologies of Witness, Testimony, Judgment (and Justice?)," Studies in History and Philosophy of Biological and Biomedical Sciences 44 (2013), 4-15, on 6-9, relying on English-language historiography from the 1970s to the early 1990s. For the different point that state practice did not match cameralist theory, see Andre Wakefield, The Disordered Police State: German Cameralism as Science and Practice (Chicago: University of Chicago Press, 2009).

${ }^{19}$ See notes $<1-3>$ above; on jurists in action, for example, Franz-Josef Arlinghaus et al., eds., Praxis der Gerichtsbarkeit in europäischen Städten des Spätmittelalters (Frankfurt a.M.: Klostermann, 2006); on a variety of experts in criminal justice: Kästner and Kesper-Biermann, Experten und Expertenwissen; quotation from André Holenstein et al., eds., Scholars in Action: The Practice of Knowledge and the Figure of the Savant in the 18th Century, 2 vols. (Leiden: Brill, 2013).

${ }^{20}$ But see recently Laura Kounine, "The Gendering of Witchcraft: Defence Strategies of Men and Women in German Witchcraft Trials," German History 31 (3) 2013: 295-317.

${ }^{21}$ This aspect of the vast literature of historical criminology focuses on construction of normality and deviance; for the accused in medico-legal discourse and criminal proceedings in early modern Germany, see Maren Lorenz, Kriminelle Körper, Gestörte Gemüter: die Normierung des Individuums in Gerichtsmedizin und Psychiatrie der Aufklärung (Hamburg: Hamburger Edition, 1999). 
${ }^{22}$ See note $<3>$ above.

${ }^{23}$ Martin Dinges, "Frühneuzeitliche Justiz: Justizphantasien als Justiznutzung am Beipsiel von Klagen bei der Pariser Polizei im 18. Jahrhundert" in: Heinz Mohnhaupt and Dieter Simon (eds), Vorträge zur Justizforschung: Geschichte und Theorie, (Frankfurt a. M.: 1992), pp. 269-292, esp. 281-3, a more developed version of which appeared in German in 2000 and in English as "The Uses of Justice as a Form of Social Control in Early Modern Europe" in Social Control in Europe, 1500-1800, ed. Herman Roodenburg and Pieter Spierenburg (Ohio State Univ. Press, 2004), 159-175; Michaela Hohkamp, Herrschaft in der Herrschaft: die vorderösterreichische Obervogtei Triberg von 1737 bis 1780 (Göttingen: Vandenhoeck und Ruprecht, 1998), ch. 4; Achim Landwehr, “ '...das ein nachbar uff den andern heimblich achtung gebe.' 'Denunciatio', Rüge und 'gute Policey' im frühneuzeitlichen Württemberg" in Denunziation und Justiz: Historische Dimensionen eines sozialen Phänomens, ed. Friso Ross and Achim Landwehr (Tübingen: edition diskord, 2000), 25-53; initiation "from below" has always been recognized in historiography of witchcraft; for a detailed example, see Robisheaux, Last Witch, 12-38.

${ }^{24}$ Rudolf Schlögl, ed., Interaktion und Herrschaft: die Politik der frühneuzeitlichen Stadt (Konstanz: UVK Verlagsgesellschaft, 2004): on communication and consensus generally and specifically in a free imperial city, Joachim Eibach, "Städtische Strafjustiz als konsensuale Praxis: Frankfurt a.M. im 17. und 18. Jahrhundert," 181-214; literature reviewed on 184-86, quotations from title and p. 188; on forms of conflict resolution generally and specifically within a territorial-administrative state: Andreas Blauert, "Sühnen und Strafen im sächsischen Freiberg vom 15. bis 17. Jahrhundert," 163-80; on mercy and leniency, Franz-Josef Arlinghaus, "Gnade und Verfahren: Kommunikationsmodi in spätmittelalterlichen Stadtgerichten," 137-62; Ulrike Ludwig, Das Herz der Justitia: Gestaltungspotentiale territorialer Herrschaft in der Strafrechtsund Gnadenpraxis am Beispiel Kursachsens 1548-1648 (Konstanz: UVK Verlagsgesellschaft, 2008).

${ }^{25}$ For emphasis on medical expertise see Dieter Emrich, Rechtsmedizinische Sachverständigentätigkeit in der freien Reichsststadt Frankfurt am Main im 16. Jahrhundert (Frankfurt a. M.: Medical Dissertation, 1990), 55-60.

${ }^{26}$ IfS Crim. 25, ff. 1, 10-11; for the social position of innkeeper in other Imperial cities, see Roeck, Bernd. Eine Stadt in Krieg und Frieden: Studien zur Geschichte der Reichsstadt Augsburg zwischen Kalenderstreit und Parität. 2 vols. (Göttingen: Vandenhoeck \& Ruprecht, 1989), vol. 1, pp. 344-6, 421-2.

${ }^{27}$ IfS Crim. 25, ff. 28v-29; geschlagen haben sollte, daß sie volgents gestorben seyhe.

${ }^{28}$ About 20 entries in the minutes of the Frankfurt city council (Ratsprotokolle: RP) and a corresponding number in the Mayors' Books (Bürgermeisterbücher: BMB) were devoted to Rode early in the proceedings; IfS RP 1550-1551, Index, s.v. Rode; IfS BMB (1550), ff. 13v, 140v-141, 155, 184, 190, 209, 215, 230v-231, 235, 250v-251, 266, 272. An Imperial city council's interpretation of its duties as framed shortly before by Emperor Charles V: Roeck, Eine Stadt in Krieg und Frieden, 215-225.

${ }^{29}$ IfS Crim. 25, ff. 23-26v, 51-54v.

${ }^{30}$ For defence strategies of accused men and women, see Gerd Schwerhoff, Köln im Kreuzverhör: Kriminalität, Herrschaft und Gesellschaft in einer frühneuzeitlichen Stadt (Bonn: Bouvier, 1991), 104-107; Dorothea Nolde, Gattenmord: Macht und Gewalt in der frühneuzeitlichen Ehe (Köln: Böhlau, 2003), chs. 11-15; Ludwig, Herz der Justitia, 173-234; Kounine, "Gendering of Witchcraft."

${ }^{31}$ IfS Crim. 6, 1v-3, 7, 8v, 10-11v, 13v.

${ }^{32}$ Ulrich Tengler, Der neue Layen-Spiegel: Von rechtmässigen ordnungen in Burgerlichen und peinlichen regimenten (Straßburg: no pub., 1518), 3, 127v; Constitutio Criminalis Carolina, $\S 147$; for similarities among criminal law texts in the 15th and 16th centuries, see Emil 
Brunnenmeister, Die Quellen der Bambergensis: Ein Beitrag zur Geschichte des deutschen Strafrechts (Leipzig: W. Engelmann, 1879); more recently Friedrich-Christian Schroeder, "Zum Verhältnis von Laienspiegel und Carolina" in Ulrich Tenglers Laienspiegel: Ein Rechtsbuch zwischen Humanismus und Hexenwahn, ed. Andreas Deutsch (Heidelberg: Winter, 2011), 26375. Pleading self-defense was a way of preventing authorities from using torture in trials. Adducing evidence of recovery pointed to death by other causes.

${ }^{33}$ The substantial literature on leprosy inspection goes back to pioneering work by Karl Sudhoff and local historians around 1900, now expanded to inspection for other diseases such as the French Pox and to poor relief: Annemarie Kinzelbach, "“an jetzt grasierender kranckheit sehr schwer darnider': 'Schau' und Kontext in süddeutschen Reichsstädten der frühen Neuzeit" in Seuche und Mensch: Herausforderung in den Jahrhunderten, ed. Carl C. Wahrmann, Martin Buchsteiner, Antje Strahl (Berlin: Duncker \& Humblot, 2012), 269-82; Fritz Dross,

"Seuchenpolizei und ärztliche Expertise: Das Nürnberger 'Sondersiechenalmosen' als Beispiel heilkundlichen Gutachtens" in Seuche und Mensch, 283-301; Mitchell L. Hammond, "Medical Examination and Poor Relief in Early Modern Germany," Social History of Medicine 23 (2010), 1-16; Claudia Stein, Negotiating the French Pox in Early Modern Germany (Aldershot: Ashgate, 2009); Stein, "Meaning of Signs"; Luke Demaitre, Leprosy in Premodern Medicine: A Malady of the Whole Body (Baltimore: Johns Hopkins University Press, 2007), chs. 1-2.

${ }^{34}$ Example of demand by a tanner's wife: certificate by Nördlingen Stadtarzt Johann Widmann for Margaretha Breydnerin; Stadtarchiv Nördlingen (hereafter StadtANö) R39, F2, 12, 1547.08 .11 .

${ }^{35}$ For some striking examples, see Demaitre, Leprosy, chs. 1-2.

${ }^{36}$ Robert Jütte, "Lepra-Simulanten: 'De iis qui morbum simulant"' in Neue Wege in der Seuchengeschichte, ed. Martin Dinges and Thomas Schlich (Stuttgart: Steiner, 1995), 25-42, on pp. 33-38.

${ }^{37}$ Annemarie Kinzelbach, “'Böse Blattern' oder 'Franzosenkrankheit': Syphilis-konzept, Kranke und die Genese des Krankenhauses in oberdeutschen Reichsstädten der frühen Neuzeit" in Neue Wege, ed. Dinges and Schlich, 43-69; Stein, Negotiating, 147-170; Hammond, "Medical Examination."

${ }^{38}$ StadtANö R39, F2, 12, 1544.09.03.

${ }^{39}$ StadtANö R39, F2, 29, 1594.11.20; for this and other contested cases in Nördlingen, see Hammond, "Medical Examination"; on perception of such behavior as women's stubbornness, see Claudia Ulbrich, "Unartige Weiber: Präsenz und Renitenz von Frauen im frühneuzeitlichen Deutschland" in Richard van Dülmen, ed., Arbeit, Frömmigkeit und Eigensinn (Frankfurt a. M.: Fischer, 1990), 13-42.

${ }^{40}$ Universitätsarchiv Tübingen, Medizinischen Fakultät (hereafter UAT): UAT 20/10, 1656.01.25: letter from bailiff at Horb to the faculty, protocol of inspection, corrected draft of response letter.

${ }^{41}$ Horb was the administrative center of a Landvogtei in Swabia and belonged to the Habsburg Empire: Christoph Fichtner, "Das mittelalterliche Horb und sein Stadtrecht" in Die Habsburger im deutschen Südwesten, ed. Franz Quarthal (Stuttgart: Thorbecke 2000), 89-98.

${ }^{42}$ Robert Jütte, Ärzte, Heiler und Patienten (München: Artemis \& Winkler, 1991); Gianna Pomata, Contracting a cure: patients, healers, and the law in early modern Bologna (Baltimore: Johns Hopkins University Press, 1998); Gentilcore, Healers and Healing, 177-210.

${ }^{43}$ For a recipe of an ointment contra lepram see Julius Zacher, "Zwei medicinische recepte," Zeitschrift für deutsches Alterthum (1867), 381-83.

${ }^{44}$ Pomata, Contracting a Cure.

${ }^{45}$ UAT 20/10, 1656.01.25: corrected draft of response letter. 
${ }^{46}$ Samuel Hafenreffer, Nosodochion: in quo cutis, eique adhaerentium partium, affectus omnes, singulari methodo et cognoscendi et curandi [...] (Ulm: Kühn, 1660).

${ }^{47}$ UAT 20/10, 1656.01.25, sealed letter of the bailiff in Horb, presented by Martin Naff.

${ }^{48}$ See note $<33>$ above; see also Jon Arrizabalaga, John Henderson, and Roger French, The

Great Pox: The French Disease in Renaissance Europe (New Haven: Yale University Press, 1997), 252-77.

${ }^{49}$ We can adduce many examples beyond the Naff case: Paul Ammann, Medicina critica sive decisoria: Centuria casuum medicinalium in Concilio Facult. Med. Lips. antehac resolutorum, comprehensa, [...] (Erfurt: Hertz, 1670), pp. 1-9, Casus 1-3 (1516, 1517, 1525/1527); Stadtarchiv Überlingen, Spitalarchiv No. 112a/2, 1665; 113, June 1532; July 1538; November 1538; StadtANö R39, F2, 12, 1544.09.03; UAT 20/10 1616.01.05; 1616.06.15; UAT 20/10, 1619.07.20; 1619.10.26.

${ }^{50}$ See notes $<9-10>$ above and David Gentilcore, "Was There a 'Popular Medicine' in Early Modern Europe?” Folklore 115 (2004): 151-166. For the spreading of knowledge about cures for the French disease by broadsheets in England, see Wear, "Popular Medicine and the New Science"; more generally on knowledge and broadsheets, Kerstin te Heesen, Das illustrierte Flugblatt als Wissensmedium der frühen Neuzeit (Opladen: Budrich, 2011); see generally Ulrich Rousseaux, "Flugschriften und Flugblätter im Mediensystem des Alten Reiches" in Johannes Arndt (ed.), Das Mediensystem im Alten Reich der Frühen Neuzeit, 1600-1750 (Göttingen: Vandenhoek \& Ruprecht, 2010), 99-114.

${ }^{51}$ Demaitre, Leprosy, 275-76; Arrizabalaga, Henderson and French, Great Pox, 271.

${ }^{52}$ See, for example, Gowing, Common Bodies; Susanna Burghartz, "Ordering Discourse and Society: Moral Politics, Marriage and Fornication during the Reformation and the Confessionalisation Process in Germany and Switzerland" in Social Control in Europe, 15001800, ed. Herman Roodenburg (Columbus: Ohio State University Press, 2004), 78-98; Gudrun Piller, Private Körper: Spuren des Leibes in Selbstzeugnissen des 18. Jahrhunderts (Köln: Böhlau, 2007), part 2 on the body and marriage relations; Edward Behrend-Martinez, Unfit for Marriage: Impotent Spouses on Trial in the Basque Region of Spain, 1650-1750 (Reno:

University of Nevada Press, 2007); and for finance-related trials focused on the female body in pregnancy, childbirth, and death, see de Renzi, "Risks of Childbirth."

${ }^{53}$ Ulm Museum (hereafter UM), AV 950 II; on the Ulm barber-surgeons, Kinzelbach, "Erudite and Honoured Artisans?"

${ }^{54} \mathrm{UM}, \mathrm{AV} 950$ II, 38-39, 1605.07.23.

${ }^{55}$ Recently on family economy and guilds: Danielle van den Heuvel, "Partners in marriage and business? Guilds and the family economy in urban food markets in the Dutch Republic', Continuity and Change, 23/02 (2008): 217-36.

${ }^{56}$ UM, AV 950 II, 38, 1605.07.23.

${ }^{57}$ Sabine von Heusinger, Die Zunft im Mittelalter: Zur Verflechtung von Politik, Wirtschaft und Gesellschaft in Straßburg (Stuttgart: Steiner, 2009), p. 116; Patrick Schmidt, Wandelbare

Traditionen - tradierter Wandel: Zünftische Erinnerungskulturen in der frühen Neuzeit (Köln: Böhlau, 2009), p. 152.

${ }^{58}$ Recent studies of "medical expertise" point out epistemological weakness yet social strength of physician testimony but do not question the category; see Silvia De Renzi, "Medical Expertise, Bodies, and the Law in Early Modern Courts," Isis 98 (2007), 315-22.

${ }^{59}$ IfS Crim. 25, 30.

${ }^{60}$ On classic consilia concerning time lapse between wound and death, see Trevor Dean, Crime and Justice in Late Medieval Italy (Cambridge: Cambridge University Press, 2007), ch. 5, esp. 101-02; early-16th-century German legal texts provided guidance on this and related kinds of case: Brunnenmeister, Die Quellen der Bambergensis, 1879, 139-41; see De Renzi, "Witnesses," 
227-28, for a related kind of case in Rome, a century later than our Frankfurt case, with consilium by Zacchias arguing that death was from disease (plague) rather than a head wound. ${ }^{61}$ IfS Crim. 25, f. 24v (ob die Hirnschall vnnd Dura vnnd pia Mater durch das schlagen entgenzet worden) and f. 44v (sie Zeugin hab am kopff nichts gesehen, sonder allein ann baiden knyen hab Engin klaine bleue mäler gehapt).

${ }^{62}$ Blumenthal, "Domestic Medicine," 519.

${ }^{63}$ See Gowing, Common Bodies, 16 ("the female body was a public affair"), 43-45 ("juries of matrons"), 53, passim.

${ }^{64}$ IfS Crim. 25, f. 25.

${ }^{65}$ IfS Crim. 25, f. 45.

${ }^{66} \mathrm{Fft}$ Crim. 25, ff. 77v-78r: "ja, er [Martin] hat mich wohl auch geschlagen, aber sollichs schlagen schadet mir nichts, wann der Klumpen im Leib nit wäre, derselbig, hab ich sorg, werde mich hinrichten und umbbringen. Dann mein Martin und ich sind unser Sachen zufrieden und eins."

${ }^{67}$ Esther Fischer-Homberger, Medizin vor Gericht: Gerichtsmedizin von der Renaissance bis zur Aufklärung (Bern: Huber, 1983); Catherine Crawford, "Legalizing medicine: early modern legal systems and the growth of medico-legal knowledge" in Legal Medicine in History, ed. Clark and Crawford, 89-116; Watson, Forensic Medicine.

${ }^{68}$ See note $<89>$ below.

${ }^{69}$ See for example Spary, Eating the Enlightenment, 8.

${ }^{70} \mathrm{UM}$, AV 950 I, 80-90, quotation on 85: Zu Erkennen, waaß Recht Ist.

${ }^{71} \mathrm{UM}$, AV 950 I, 81-89. With few exceptions, the record of the interrogation by the sworn masters concurs with the previous account in the provost's letter but is more precise in providing names.

${ }^{72}$ UM, AV 950 I, 80-81, 84.

${ }^{73} \mathrm{UM}, \mathrm{AV} 950 \mathrm{I}, 90$.

${ }^{74}$ IfS Crim. 6, f. 5.

${ }^{75}$ Hans von Gerdorff, Feldbuch der Wundartzney (Straßburg: Johannes Schott, 1517), fol. 35; Brunschwig, Wund Artzney, 1513, 2, 21-25.

${ }^{76}$ IfS Crim. 6, 7-7v.

${ }^{77}$ IfS Crim. 6, 8-10.

${ }^{78}$ IfS Crim. $6,14 \mathrm{v}-15$.

${ }^{79}$ IfS Crim. 6, f. 7-7v.

${ }^{80}$ On the Carolina as "landmark in the history of forensic medicine": Crawford, "Medicine and the Law," 1623; Watson, Forensic Medicine, 18, 20-22.

${ }^{81}$ IfS Crim. 25, f. 42.

${ }^{82}$ IfS Crim. 25, ff. 61v-62, 64v, 65, 67v, 68, 69v, 72, 73v-74v.

${ }^{83}$ IfS Crim. 25, 27-43.

${ }^{84}$ IfS Crim. 25, 44-45.

${ }^{85}$ IfS Crim. 25, 46v-48 (erstes Befragungsprotokoll), 74-75 (zweites Befragungsprotokoll).

${ }^{86}$ See most recently Rublack, The Astronomer and the Witch, esp. 80-83, 157-76, including interpretation of bodily signs by family members, both "lay" and medically trained (barbersurgeon, royal physician). Our net could be cast even more widely to include civil law cases and cases that involved medical testimony but that we do not include here, such as infanticide, poisoning, impotence, and insanity. Most studies consider one or two kinds of case and one or two kinds of expert; studies focusing on accused persons and their familial and social milieux, such as Lorenz, Kriminelle Körper, tend to address questions of power, cultural meaning, social norms, and their construction; but for knowledgeable agency of the accused, see now Kounine, "Gendering of Witchcraft." The most nuanced and in-depth study of a wide variety of early 
modern German cases of public inquiry remains David Warren Sabean, Power in the Blood: Popular Culture and Village Discourse in Early Modern Germany (Cambridge: Cambridge University Press, 1984).

${ }^{87}$ H. M. Collins and Robert Evans, Rethinking Expertise (Chicago: University of Chicago Press, 2007).

${ }^{88}$ Golan, Laws; literature surveyed in Watson, Forensic Medicine, who cautions against applying the "expert witness" concept earlier than the 18th century (p. 47).

${ }^{89}$ Blumenthal, "Domestic medicine," 517, 523, 530; McClive, "Blood and Expertise"; both developing the research program suggested by de Renzi, "Witnesses of the body," 221, 227ff. and "Risks of Childbirth," 550, 554, 570-77, on trials as windows on interaction of expert and lay knowledge.

${ }^{90}$ Arguing against thinking in expert/lay dichotomies: Brian Wynne, "May the Sheep Safely Graze? A Reflexive View of the Expert-Lay Knowledge Divide" in Risk, Environment and Modernity: Towards a New Ecology, ed. Scott Lash, Bronislaw Szerszynski, and Brian Wynne (London: SAGE, 1998), 44-84; critical of the "lay expertise" concept and arguing for distinction: Collins and Evans, Rethinking Expertise, 48-49.

${ }^{91}$ See, for example, Sheila Jasanoff, "The Eye of Everyman: Witnessing DNA in the Simpson Trial," Social Studies of Science, 1998, 28:713-740.

${ }^{92}$ A revealing limit case of this is food, on which "everybody is an expert": Spary, Eating the Enlightenment, p. 290.

${ }^{93}$ For criminal justice, the research on these points has been systematic; see Eibach, "Städtische Strafjustiz." The pattern seems to hold for the other kinds of proceeding examined in this paper, though research on these has not been systematic.

${ }^{94}$ Eibach, "Städtische Strafjustiz," 189-90.

${ }^{95}$ See generally Andrew W. Russell, ed., The Town and State Physician in Europe from the Middle Ages to the Enlightenment (Wolfenbüttel: Herzog August Bibliothek, 1981); for Germany, see most recently Ruth Schilling, Sabine Schlegelmilch, and Susan Splinter, "Stadtarzt oder Arzt in der Stadt? Drei Ärzte der Frühen Neuzeit und ihr Verständnis des städtischen Amtes," Medizinhistorisches Journal, 46 (2011): 99-133.

${ }^{96}$ A well-documented example for the 16th and 17th centuries is Zurich: Gustav Adolf Wehrli, Die Krankenanstalten und die öffentlich angestellten Ärzte und Wundärzte im alten Zürich (Zürich: Leemann, 1934), 39-40, 83, 86; see also Schilling, Schlegelmilch, and Splinter, "Stadtarzt," 101, 118-19.

${ }^{97}$ Outside in principle, at least: in practice, in smaller towns and even in cities, it could be difficult to avoid personal or prior healing relations. In the Rode case, for example, one of the barber-surgeons (Jacob Stolhofen) declared a friendship with Rode. 